\title{
Germination of chiltepín with mixed substrates and application of gibberellic acid
}

\author{
Mejoramiento del proceso de germinación de chiltepín, mezclando sustratos y \\ aplicando ácido giberélico
}

\author{
BASILIO-MORA, Marisol†*, HERNÁNDEZ-SALGADO, Julio César and JÚAREZ-BARRIOS, Diana \\ Universidad Xicotepetl A.C \\ ID $1^{\text {st }}$ Author: Marisol, Basilio-Mora / ORC ID: 0000-0001-7210-2987, CVU CONACYT ID: 589851 \\ ID $1^{\text {st }}$ Co-author: Julio César, Hernández-Salgado / ORC ID: 0000-0003-1983-4163, CVU CONACYT ID: 1173771 \\ ID $2^{\text {nd }}$ Co-author: Diana, Juárez-Barrios / ORC ID: 0000-0002-9916-4173, CVU CONACYT ID: 1173985
}

DOI: $10.35429 /$ JSL.2021.25.8.9.15

Received July 30 2021; Accepted December 30, 2021

\begin{abstract}
The demand for chiltepín is increasing, since in addition to the traditional sale of fresh and dried fruit in the street and regional markets, there is also the commercialization of derived products such as pickles, sauces and dehydrated products in chain stores, the market is supplied by the collection of wild fruits. This has made harvesting intense and aggressive, because collectors cut productive branches or the entire plant in order to harvest a larger quantity, limiting its possibilities for regeneration. Therefore, it is proposed to improve the germination of chiltepín seeds and to evaluate the obtaining of good quality seedlings through substrate mixtures and application of gibberellic acid (AG3) at 400 parts per million (ppm). The results of the research indicate that at seven days treatments $4,3,7$ and 8 differ significantly from the other treatments, while by day 31 treatments 1,7 and 8 are significantly different from the others, with a significance of $95 \%$; for the number of roots the best treatment was $\mathrm{T} 1$ for the evaluation on day 31 after planting (dds).
\end{abstract}

Physiologic, Capsicum annuum var. aviculare, germination

\begin{abstract}
Resumen
La demanda de chiltepín va en aumento, ya que a la venta tradicional de fruto fresco y seco en la calle y mercados regionales, se agrega la comercialización de productos derivados como escabeches, salsas y deshidratados en cadenas de tiendas comerciales, el mercado se abastece de la colecta de frutos silvestres. Esto ha hecho intensa y agresiva la recolección, debido a que los colectores por cosechar mayor cantidad, cortan las ramas productivas o la planta completa, limitando sus posibilidades de regeneración. Por lo que se propone mejorar la germinación de semillas de chiltepín y evaluar la obtención de plántulas de buena calidad a través de mezclas de sustratos y aplicación de ácido giberélico $\left(\mathrm{AG}_{3}\right)$ a 400 partes por millón (ppm). Los resultados de la investigación indican que a los siete días los tratamientos 4, 3, 7 y 8 difieren significativamente de los demás tratamientos, mientras que para el día 31 los tratamientos 1,7 y 8 son significantemente diferentes de los demás, con una significancia del 95\%; para el número de raíces el mejor tratamiento ha sido el T1 para la evaluación el día 31 después de siembra (dds).
\end{abstract}

Fisiológico, Capsicum annuum var. aviculare, germinación

Citation: BASILIO-MORA, Marisol, HERNÁNDEZ-SALGADO, Julio César and JÚAREZ-BARRIOS, Diana. Germination of chiltepín with mixed substrates and application of gibberellic acid. Journal Simulation and Laboratory. 2021, 8-25: 9-15

*Correspondence to Author (e-mail: marisol.basilio.mora@gmail.com)

$\dagger$ Researcher contributing as first Author. 


\section{Introduction}

64 types of chili peppers have been identified, Oaxaca is the state with the greatest diversity with at least 25 types, followed by Guerrero with 12 records, Puebla with 10 and Veracruz with nine. In the north of the country, the states of Nuevo León, Coahuila, Chihuahua, Sonora and the Baja California Peninsula registered different variants of the piquín, wild, chiltepin or "del monte" chili (Capsicum annuum var., Aviculare. Dierb D ' Arcy \& Eshbaugh or glabriusculum); Around this diversity of chili peppers, a local economy develops on which families depend to survive or improve family well-being, many of these continue to be cultivated thanks to the great interrelation with culinary wealth, immersed in the ethnic-cultural complex that characterizes to Mexico (Vera et al., 2016).

The most consumed chili peppers are generally cultivated, although there are also some widely consumed species that have not been properly domesticated and that are obtained through the collection of wild plants. One of these cases is the chiltepin, which is found in almost the entire national territory (Bañuelos et al., 2008). Cano Vázquez et al., (2015), mention that in the north of the country there are some orchards that cultivate chiltepín for commercial purposes, but there is no updated information about production and prices, only its backyard cultivation for self-consumption ( Pedraza and Gómez, 2008).

The demand for chiltepín is increasing, since to the traditional sale of fresh and dried fruit in the street and regional markets, the commercialization of derivative products such as pickles, sauces and dehydrated products in commercial chain stores is added (SandovalRangel et al. ., 2018). Therefore, this market is supplied almost entirely by the collection of wild fruits (Bran et al., 2007). The problem in this way of obtaining it is that there is no control over the collected plants and those natural genotypes are not replaced, which puts them in danger of extinction (Bañuelos et al., 2008).

In the recognized diversity of chiltepín there are morphological variations, such as in the size of the fruit, which is very small in the states of Sonora and Tamaulipas, compared to those from the states of Veracruz and Puebla.
Variations in plant and seed characteristics have also been reported, which could influence germination (Hernández-Verdugo et al., 2010). The low and variable germination rate of 5 to $80 \%$ (Rodríguez del Bosque et al., 2003), is an important impediment to having certified seed that allows establishing commercial production batches of this species and is attributed to physical or physiological latency, caused by the impermeability of its testa or cover, immaturity of the seed or rest of the embryo.

To solve this problem, different techniques are reported, among them, chemical and physical scarification, conditioning or treatment of the seed prior to sowing with gibberellic acid, potassium nitrate, hydrogen peroxide (Rodríguez del Bosque et al, 2003; Cano-Vázquez et al., 2015).

For what was previously reported, it is necessary to look for options to conserve existing wild populations, specifically in the Sierra Norte de Puebla region and it is considered that one of the strategies is to solve the problem of seed germination, and thus avoid the collection of fruits. of wild plants, through the domestication and agronomic production of these chili peppers.

Therefore, in the present investigation, the germination percentage of chiltepin was evaluated in different substrate mixtures with and without application of gibberellic acid at 400 ppm at 7, 14, 21 and 31 days, as well as the root size, number of roots, number of leaves and seedling size of the same plants at 31 days after sowing.

\section{Methodology}

The methodological process is made up of 2 phases; Phase 1 is called recognition and validation of the experimentation process and is analyzed through 3 stages (Figure 1.2 Stages that constitute Phase 1), in Phase 2 the regional substrate mixtures were made and gibberellic acid (AG3) was applied at 400 ppm through a series of experiments on chiltepin seeds (application of experimental processes). 
1. Phase 1: Recognition and validation of
the experimentation process

Stage 1

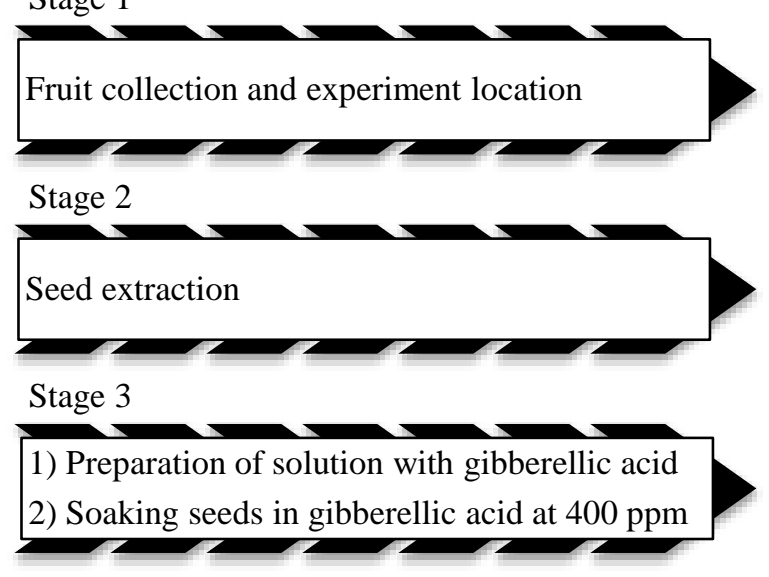

Figure 1.2 Stages that constitute Phase 1 Source: Own Elaboration

The collection of fruits for seeds of wild plants of chile piquín was carried out in the community of Santa Cruz Grande belonging to the municipality of Xicotepec, with the aim of obtaining the seeds to begin the experimental work on germination, later the seed was transferred to Xicotepec, where the drying process was carried out under shade, which lasted two weeks, and then the seeds were extracted from the fruit at the facilities of the Xicotepetl AC University, where $0.04 \mathrm{~g}$ of gibberellic acid (BIOGIB $\left.{ }^{\circledR}\right)$ was weighed. On a Velab brand scale and added to $10 \mathrm{~L}$ of water, the seeds were introduced into the water with gibberellic acid for 24 hours.

The next day the seed was removed, it was placed on brown paper so that they lost moisture, the next thing was to start the germination process in the different treatments with the substrate already disinfected with captan at $1.5 \mathrm{~g}$ - L-1 at the same time They disinfected the trays, once ready, the substrates of the different treatments were prepared, and later the mixtures were made according to the treatments.

\begin{tabular}{|l|l|}
\hline Treatments & \multicolumn{1}{|c|}{ Description of treatments } \\
\hline T1 & AG3 $+70 \%$ Peat moss $+30 \%$ agrolite. \\
\hline T2 & AG3 $+100 \%$ mountain land \\
\hline T3 & AG3 $+40 \%$ agrolite $+60 \%$ vermicompost. \\
\hline T4 & AG3 $+50 \%$ agrolite $+30 \%+$ \\
T5 & vermicompost $+20 \%$ litter. \\
T6 & $70 \%$ Peatmoss $+30 \%$ agrolite. \\
T7 & $100 \%$ mountain land \\
T8 & $40 \%$ agrolite $+60 \%$ vermicompost. \\
& $50 \%$ agrolite $+30 \%$ vermicompost $+20 \%$ \\
\hline
\end{tabular}

Table 1 Description of Treatments Source: Self Made

ISSN: 2410-3462

ECORFAN® All rights reserved
Data collection was carried out at 7, 14, 21 and 31 days; Counting how many plants germinated per treatment, at 31 days with the support of a rule, the size of the root and plant was measured for each treatment, as well as counting the number of leaves of each plant of each treatment..

\section{Results}

\section{Variable germination and emergency Date: March 22, 2019}

To determine the significance of the eight types of treatments applied to the chiltepin plants, 4 repetitions are carried out, subsequently through the Tukey Test it is determined if the means of these are significantly the same or different. The wide Tukey Test confidence intervals allow less precise estimates to be obtained, but limit the probability that one or more confidence intervals do not contain the true difference to a maximum of $5 \%$. For the Tukey test of germination of 7 days it is observed that treatments 4, 3, 7 and 8 are significantly different from the total group of treatments, this considering an error of 5\%, this is clearly observed in the graphs presented below.

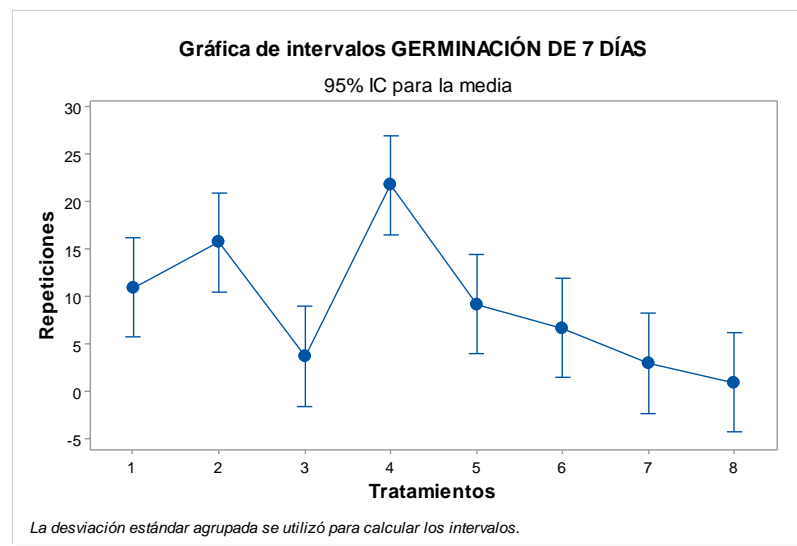

Graph 1

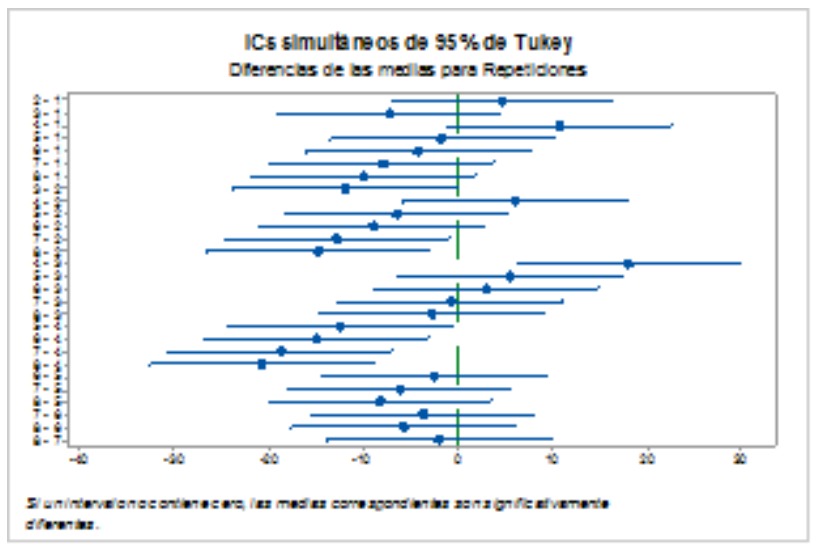

Graph 2

BASILIO-MORA, Marisol, HERNÁNDEZ-SALGADO, Julio César and JÚAREZ-BARRIOS, Diana. Germination of chiltepín with mixed substrates and application of gibberellic acid. Journal Simulation and Laboratory. 2021 


\section{Variable germination and emergency Date: March 29, 2019}

Now, as can be seen in Graphs, when the 8 treatments exposed to a germination process of 14 days were subjected to a Tukey test with 95\% significance, unlike the previous 7-day test, the significantly different groupings are as follows. Treatments 1, 4, 7 and 8. Graphically in the mean differences the intervals are aligned to the left.

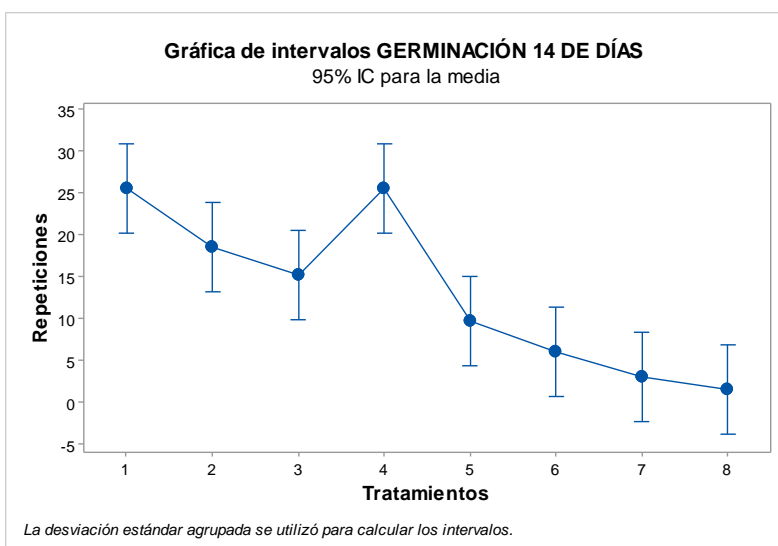

Graph 2

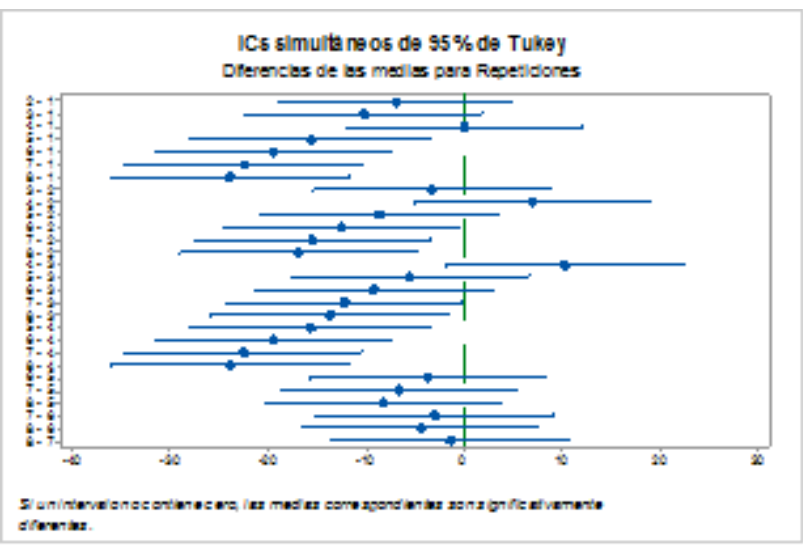

Graph 3

\section{Variable Germination And Emergency Date: April 5, 2019}

Considering the germination and emergence variable of new chiltepin plants, 21 days of germination are taken as a reference. To evaluate the results, the Tukey test is used with $95 \%$ confidence, where the means of the 8 treatments subjected to 4 repetitions are compared. As shown in the Graph, the significantly different treatments are 1,7 and 8. Which means that their germination in number of seedlings is different from the other 5 treatments where at least they share similarity with one treatment.

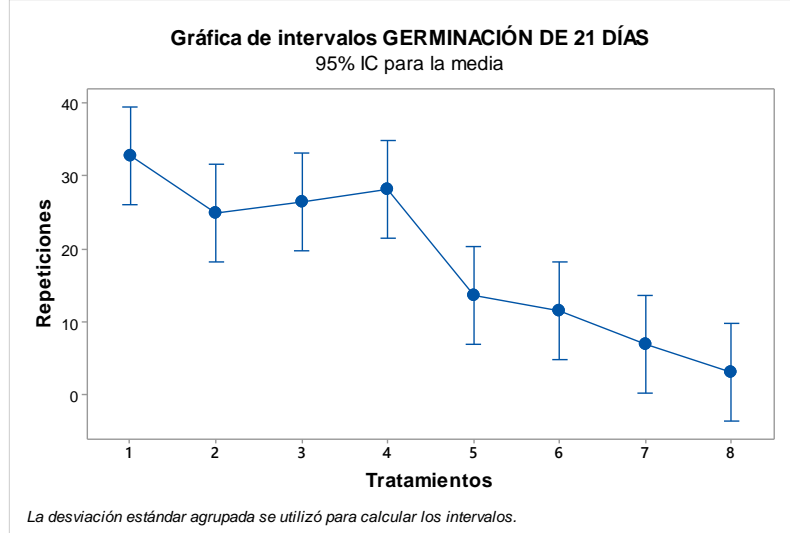

Graph 4

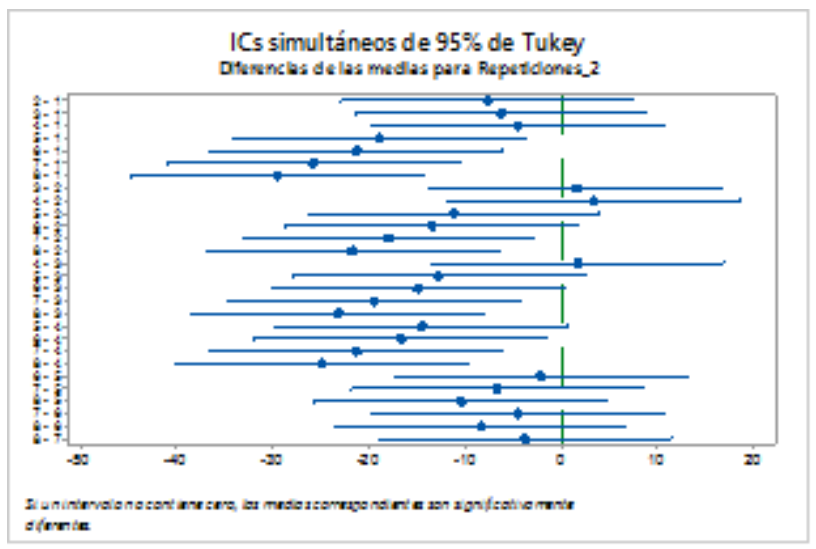

Graph 5

\section{Variable germination and emergency Date: April 15, 2019}

The last experiment considering the same variables of germination and seedling emergence, only this time in a period of 31 days. It is observed that through the Tukey Test, as in the previous experiment, treatments 1,7 and 8 are significantly different from the others, with a significance of $95 \%$. Representing a difference in the emergence of the number of seedlings.

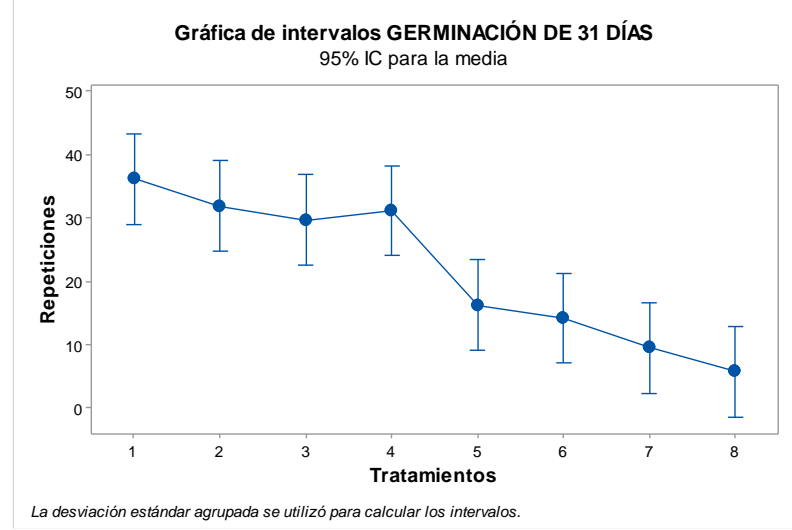

\section{Graph 6}




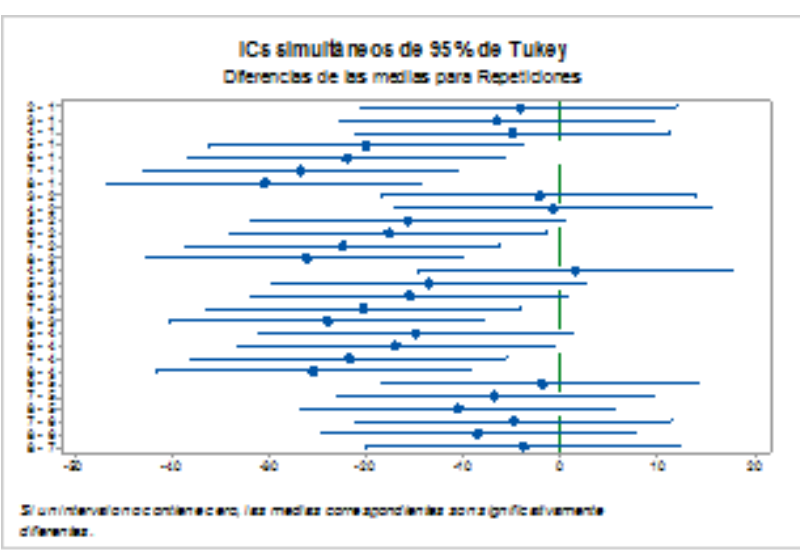

Graph 7

\section{Variable root size $(\mathrm{cm})$}

Date: April 15, 2019 (31 AD)

For the validation of the growth of the chiltepin seedlings, the size of the root of each one in centimeters is also recorded and quantified, this for the period of 31 days since this period is easier to measure the root of each of the plants. In this sense, applying the Tukey test with 95\% significance for the 8 treatments and with 4 repetitions each, it is identified that the means of the groups are significantly equal, so there is no evidence that there are differences in the size of the the roots.

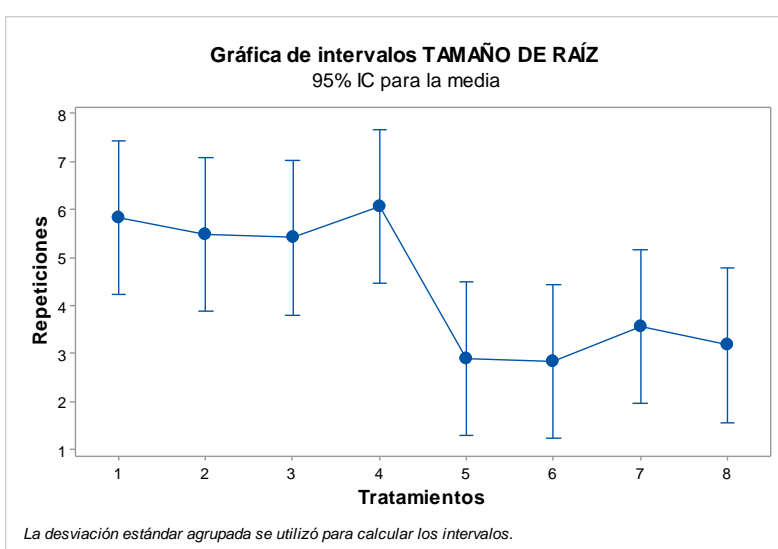

Graph 8

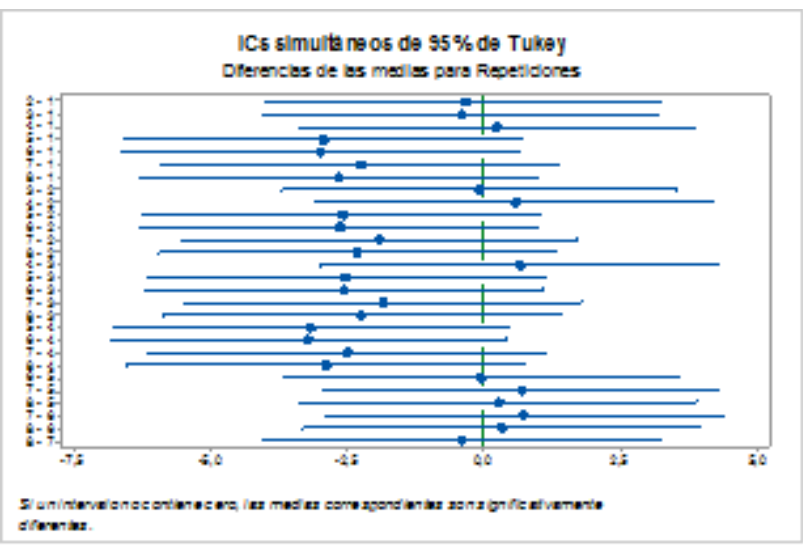

\section{Variable Number of Roots Date: April 15, 2019 (31 AD)}

Complementing the previous analysis, the number of roots of chiltepin plants is counted, again in a counting period 31 days after sowing. Unlike the previous study, when applying the Tukey test with $95 \%$ reliability and subjecting the 8 treatments in 4 repetitions, the significantly different groupings correspond to treatments 1 , 5, 6 and 8; therefore, treatments 4, 3, 2 and 7 share equalization in significant means with at least one group.

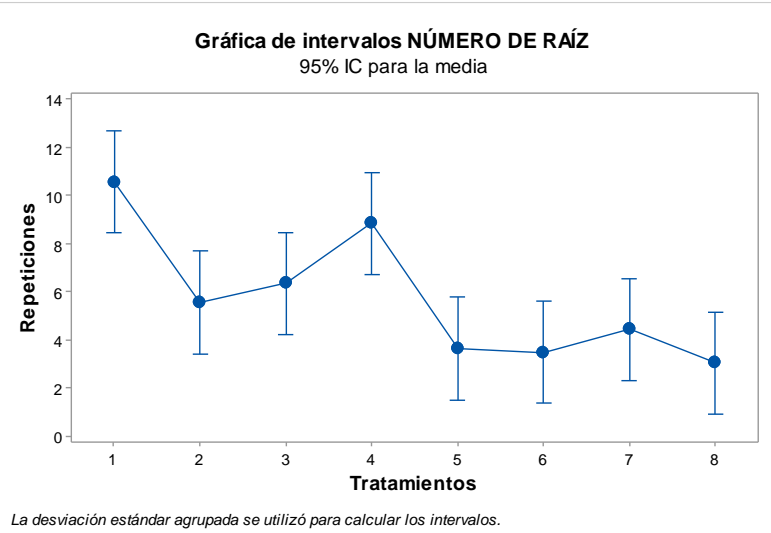

Graph 10



\section{Graph 11}

\section{Variable number of sheets \\ Date: April 15, 2019 (31 AD)}

Likewise, the number of leaves in the seedlings resulting from a germination process of 31 days is considered. Again, the 8 different treatments with 4 repetitions each are taken as a reference. When executing the Tukey test with significance of $95 \%$, it was found that the means of the treatments are equal, so they share similarity in the number of leaves regardless of the treatment applied. 


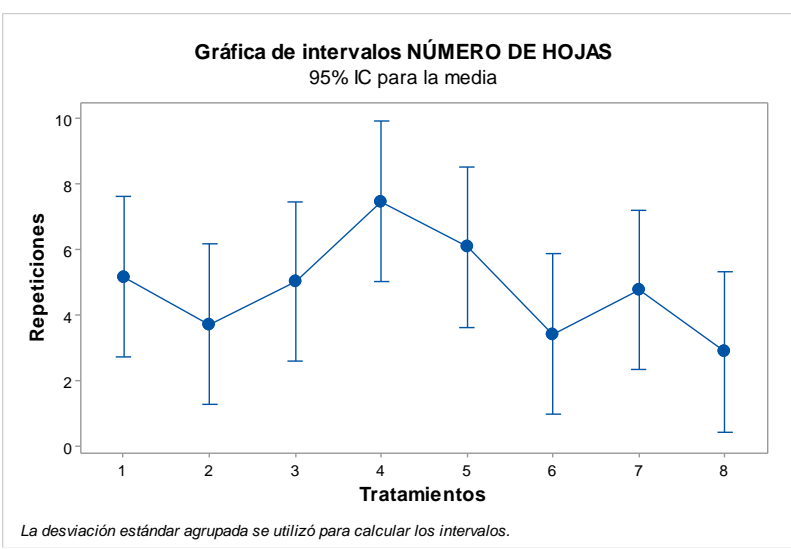

Graph 12

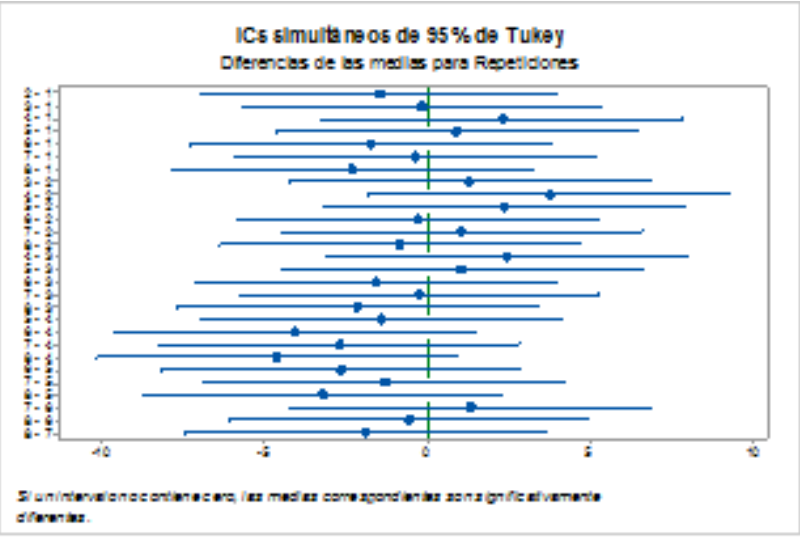

Graph 13

\section{Variable plant size $(\mathrm{cm})$ \\ Date: April 15, 2019 (31 AD)}

Finally, in addition to the variables mentioned above, the size of the plant in $\mathrm{cm}$ is studied, for a germination and growth period of 31 days. The Tukey test applied shows that the 8 treatments are significantly equal, submitted to 4 repetitions with a reliability of $95 \%$. Which means that the applied treatment does not significantly influence the size of the chiltepin plant, so any of these works with the same effect.

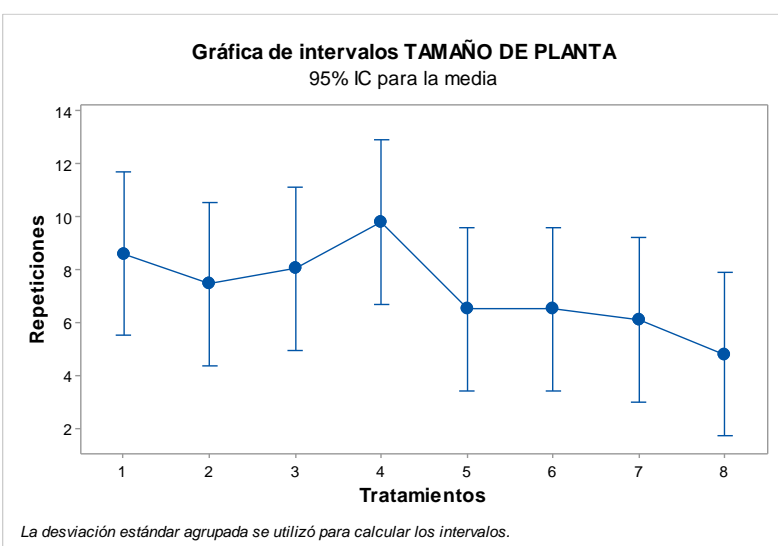

Graph 14

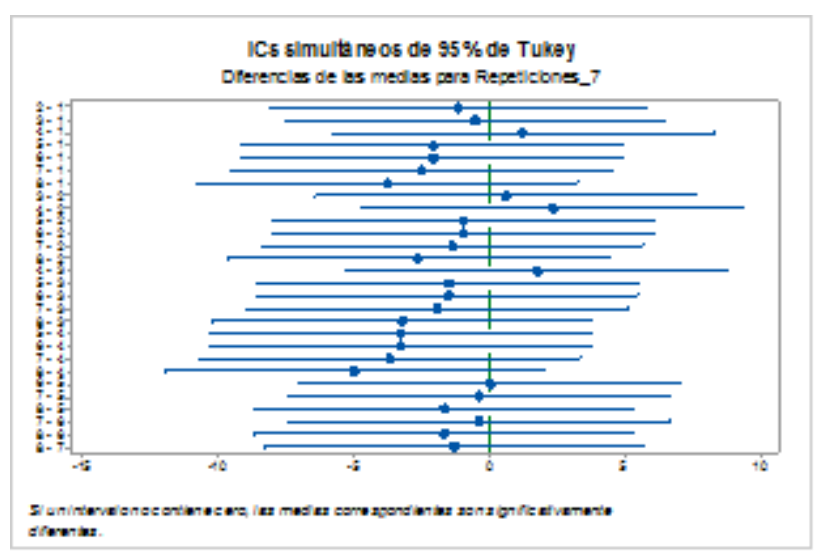

\section{Graph 15}

\section{Annexes}

\section{Acknowledgments}

To the Universidad Xicotepetl A.C. for financing this research project.

\section{Conclusions}

The research results indicate that at seven days treatments 4, 3, 7 and 8 differ significantly from the other treatments, while on day 31 treatments 1,7 and 8 are significantly different from the others, with a significance $95 \%$; for the number of roots, the best treatment was $\mathrm{T} 1$ for the evaluation on day 31 after sowing (dds). The results indicate that the AG3 at 400 ppm does influence the germination of chiltepin seeds.

\section{References}

Bañuelos, N.; Salido, P. L. y Gardea, A. (2008). Etnobotánica del chiltepín. Pequeño gran señor en la cultura de los sonorenses. Estudios Sociales Hermosillo, Son. 16:177-205.

Bran, R. A. A.; Moya, C.; Ponce, P.; Álvarez, M. y Varela, M. (2007). Diagnóstico participativo de las condiciones socioculturales asociadas a la conservación de los chiles silvestres (Capsicum spp.), en la depresión central de Chiapas, México. Cultivos Tropicales. 28(1):69-73.

Cano, V. A; López, P. M. C.; Zavaleta, M. H. A.; Cruz, H. N.; Ramírez R. I.; Gardea, B. A. y González, H. V. A. (2015). Variación en grados de latencia en semillas entre colectas de chile piquín (Capsicum Annuum Var. Glabriusculum). Bot. Sci. 93(1):175-184. 
Hernández-Verdugo S., López-España R.G., Porras F., Parra-Terraza S. T., VillarrealRomero M. y Osuna-Enciso T. 2010. Variación en la germinación entre poblaciones y plantas de chile silvestre. Agrociencia 44:667-677.

Pedraza R. L. C y Gómez, G. A. A. (2008). Análisis exploratorio del mercado y la comercialización de chile piquín $(C$. annuиm var. aviculare Dierb.) en México. Tecsistecatl, 1(5).

Rodríguez, Del B. L. A.; Ramírez, M. M y Pozo, C. O. (2003). El cultivo del chile piquín bajo diferentes sistemas de producción en el noreste de México. In: memoria del 1er. Simposio regional sobre chile piquín: Avances de investigación en tecnología de producción y uso racional del recurso silvestre. INIFAP-CIRNE. Campo Experimental Río Bravo Tamaulipas. Publicación especial Núm. 26. México. 1-16 p.

Sandoval-Rangel, A., Tapia González, A., González Fuentes, J. A., \& Benavides-Mendoza, A. (2018). Edad, beneficio y ácido giberélico afectan la germinación y producción de planta de chile piquín. Revista mexicana de ciencias agrícolas, 9(SPE20), 4199-4209.

Vera, S. K. S., Cadena, I. J., Latournerie, M. L., Santiaguillo, H. J. F., Rodríguez, C. A., Basurto, P. F. A., ... \& Ríos, S. E. (2016). Conservación y utilización sostenible de las hortalizas nativas de México. Servicio Nacional de Inspección y Certificación de Semillas. México. 